\title{
Hydrometeorological Drought Hazard and Vulnerability Assessment for Northern Bulgaria
}

\author{
Kalina RadevaA, Nina Nikolova ${ }^{A^{*}}$ \\ Received: February 03, 2020 | Revised: April 20, 2020 | Accepted: April 21, 2020 \\ doi: $10.5937 / g p 24-25074$
}

\begin{abstract}
In recent years, threats of natural origin, including those associated with the occurrence of drought is a topic that arouses interest in representatives of local government agencies, federal governmental authorities, scientific communities and residents of cities and villages. A significant part of the economy of Northern Bulgaria is agricultural, which increases the need for careful water management and planning. The aim of this study is to identify the drought hazard with regard to its spatial extends, frequency and severity and to assess the vulnerability to drought in Northern Bulgaria at the regional scale (NUTS-2). The standardized precipitation index (SPI), Standardised Precipitation-Evapotranspiration Index (SPEI) and Streamflow Drought Index (SDI) at 12-month time step for the period 1961-2012 were used to obtain drought hazard index (DHI). In order to assess drought vulnerability, Drought Vulnerability Index (DVI) was calculated based on the following parameters: population density, municipal water use, industrial water use, agricultural water use, and public water services. The results of the study show low DHI values and homogeneous distribution of drought hazard in the north part of Bulgaria. However, the drought vulnerability in the investigated area is very high due to the higher consumption of water by industry, municipal water supply, and extensive agricultural lands. Our results provide an elaborated understanding of the drought hazard and drought vulnerability and will be helpful as an early step in the development of risk-based drought management plans.
\end{abstract}

Keywords: Drought, SPI, SDI, hazard, vulnerability, Northern Bulgaria

\section{Introduction}

Drought affects more people than any other natural hazard and it is considered by many to be the most complex but least understood of all-natural hazards (Hagman, 1984). The causes of this phenomenon are not well recognized yet, and its effects are of a different nature than, for example, flood events. They grow over time, becoming visible in the long term and extend to much larger areas. It occurs in both high and low rainfall areas and virtually all climate regimes. According to the climate models increasing of drought and prolonged dry periods combined with high temperatures are expected during the 21st century (Dai, 2013; Trnka et al., 2011; Trnka et al., 2015). This fact requires further development of water consumption surveys in various sectors.

Due to various causes and consequences, different types of droughts are analyzed in the scientific publications. The classic classification of droughts is given by Wilhite and Glantz (1985) who determine four categories: meteorological, agricultural, hydrological, and socioeconomic drought. From the meteorological point of view, the drought is associated with waterless periods with different duration. Meteorological drought can be determined "on the basis of the degree of dryness (in comparison to some "normal" or average amount) and the duration of the dry period" (Na-

\footnotetext{
A Sofia University, Faculty of Geology and Geography, Sofia, Bulgaria; kradeva@gea.uni-sofia.bg; nina@gea.uni-sofia.bg

* Corresponding author: Nina Nikolova; e-mail: nina@gea.uni-sofia.bg
} 
tional Drought Mitigation Center - NDMC). The essential characteristics of meteorological drought are intensity and duration (Wilhite, 2000). Instead of meteorological drought, some authors use the term atmospheric drought (Koleva \& Alexandrov, 2008) or climatological drought (Tate \& Gustard, 2000). The main measure of drought is insufficient rainfall for a particular activity, i.e. crop growth, water supply for irrigation, the water level in dams (WMO, 1993; Alexandrov, 2006). Hydrological drought is related to the impact of meteorological drought and occurs when the long-term droughts lead to reducing of river runoff and groundwater (Koleva \& Alexandrov, 2008). Tate and Gustard (2000) analyze hydrological drought as river flow drought and groundwater drought. Often, drought may be defined in terms of the differences between water supply and water demand time series. When demand exceeds supply, the water shortages occur, which represents the starting point of a drought (ICID, 2017). In order to make a comprehensive research on drought, the type, the intensity, the duration, the spatial range, and the impact have to be examined. Several studies on drought provide details about its characteristics and occurrence in Bulgaria during the last decades or century (Knight et al., 2004; Koleva \& Alexandrov, 2008; Alexandrov, 2006; Alexandrov, 2011; Nikolova et al., 2012, Popova et al., 2014). Tran et al. (2002) point out that the drought can occur at any time, extend over a long period, and over large areas to a very severe level in Bulgaria. On the base of Cumulative Precipitation Anomalies and Standardized Precipitation Indices Nikolova \& Alieva (2011) analyze dry periods in the Danube River Plain (Bulgaria). Popova et al. (2015) evaluate maize crop risk in relation to observed trends to drought. The potential in application of atmospheric drought index as a predictor of soil drought in the agricultural regions of Southern Bulgaria was analyzed by Georgieva et al. (2017). The occurrence of hydrological and meteorological drought in North Bulgaria (Danube River Plain) is characterized by Radeva et al. (2018). Drought and heat are identified as a major abiotic stress that reduce crop productivity in Bulgaria according to Petkova et al. (2019) Water shortages and increasing drought conditions were also identified by experts in neighboring regions in Serbia, Romania and Hungary (Milošević \& Savić, 2013; Urošev et al., 2016; Szabo et al. 2019). The impact of drought on crop yield in Europe including Bulgaria was investigated by Trunka et al. (2016).

The economic development requires the satisfaction of water needs, both in society and in the economy. Bulgaria belongs to countries with limited water resources. Their high variability of occurrence in time and space causes necessity of rational water management. Recognition of the phenomenon of drought as well as developing methods of counteracting its effects should be an element of national strategies, plans and programs, and a detailed discussion of the problem should take place at the all levels of government. Drought preparedness planning should be considered to minimize the effects of drought on people and resources. For this goal, drought components, called hazard and vulnerability, have to be quantified. While hazard is a probability of occurrence of an event, vulnerability refers to the exposure to the hazard.

The overall objective of the present paper is to bring clarification of the drought hazard in Northern Bulgaria. The first stage of the research is an analysis of meteorological and hydrological droughts in terms of their duration and magnitude using standardized precipitation index (SPI), Standardized Precipitation-Evapotranspiration Index (SPEI) and Streamflow drought index (SDI). The second stage is drought vulnerability and drought hazard assessment in Northern Bulgaria. The research work is based on hydro-meteorological and socio-economic data. Assessment of drought hazard as well as vulnerability to drought at the regional scale may allow for better land use planning and water resource management during drought conditions in Northern Bulgaria. The results from the present study could be used in the development and implementation of wide range of measures and programs to reduce the negative impact of droughts.

\section{Study area and data}

The study area includes Northern Bulgaria and the main investigated territory is the Danubian plain located to the north of the main ridge of the Balkan Mountains and south of the Danube river. The relief is dominated by lowlands, hills and plateaus in the east (Figure 1). The area covers a total surface area of about $48,596 \mathrm{~km}^{2}(43,7 \%$ of the total surface area of Bulgaria) and has a population of 2,041,296 (30\% of its total population). The region comprises three administra- tive regions NUTS - Severozapaden (Northwest), Severen centralen (Northcentral) and Severoiztochen (Northeast) (Figure 1).

Northern Bulgaria constitutes the largest water region in the country administered by the Danube River District. The total freshwater resources, excluding those in the Danube River, are estimated at 5,371 billion $\mathrm{m}^{3}$, based on the long-term annual rainfall data for 1981-2014. The average annual per capita volume is 

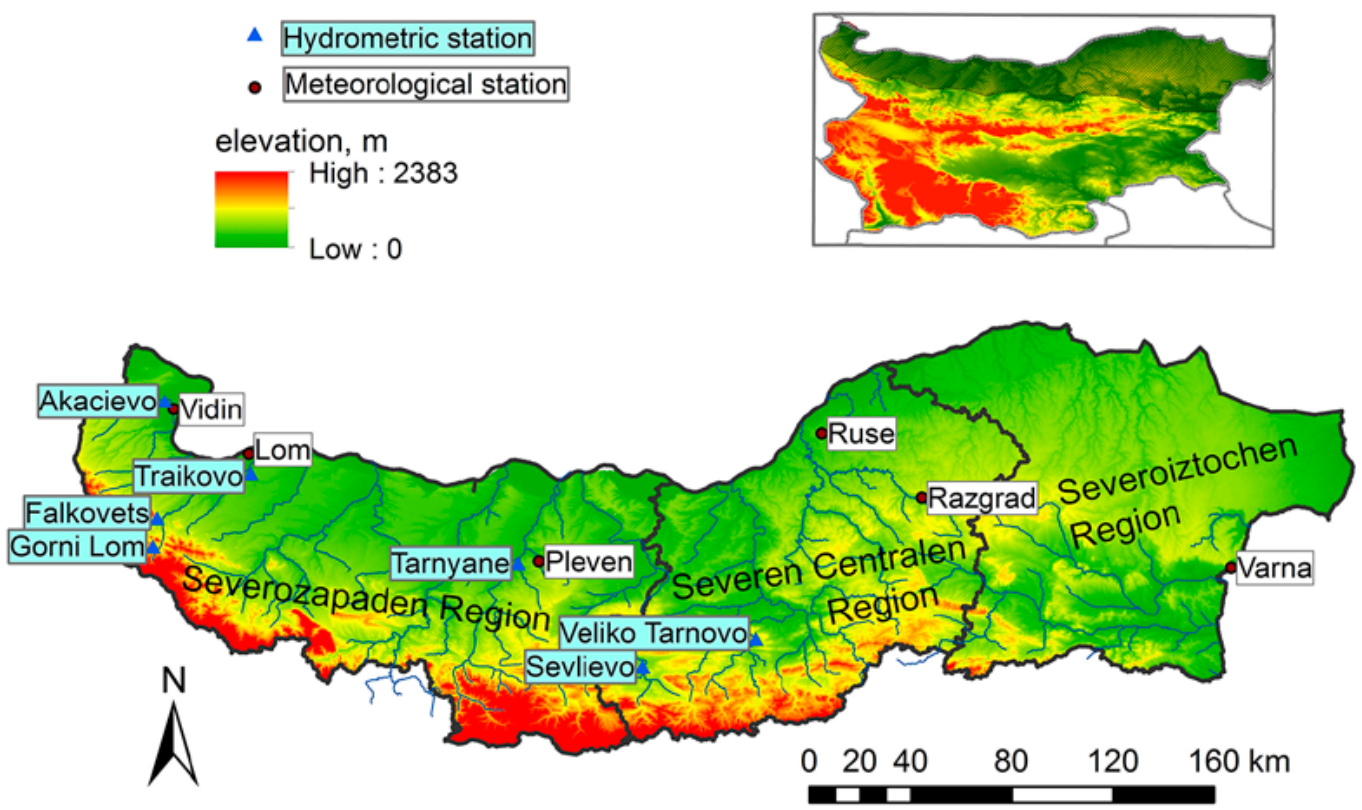

Figure 1. Studied area and location of hydrometric stations and meteorological stations used for the research

about $1,610 \mathrm{~m}^{3}$ and the usable part of it is from 800 to $1,000 \mathrm{~m}^{3} /$ capita/yr (average for Europe it is $5,300 \mathrm{~m}^{3} /$ capita/yr) (NSMDWS, 2012). The fact that more than $80 \%$ of the total freshwater resources are formed outside the territory of Northern Bulgaria indicates the existence of a water barrier in terms of securing access to water resources.

The annual precipitation varies from 500 to 600 $\mathrm{mm}$ and the annual evaporation is from 450 to 500 $\mathrm{mm}$. The maximum of the annual cycle of precipitation is in June (in some places in May) with values between $70-$ and $90-\mathrm{mm}$. The monthly maximum is lower $(60-70 \mathrm{~mm})$ in the north-west (station Vidin) and in the eastern part of the investigated area. The mean annual temperature is $11-12{ }^{\circ} \mathrm{C}$ (Topliiski, 2006).

The seasonal distribution of precipitation shows maximal values in summer and spring in most of the investigated territory. The difference is observed in the east part of the area (station Varna) where the seasonal amounts of precipitation are relatively evenly distrib- uted with a slight predominance of autumn and winter values over summer and spring. In relation to the annual precipitation totals, the regions of Lom and Pleven (central part) and Varna and Silistra (eastern part) are defined as arid areas (Alexandrov, 2011).

According to updated River Basin Management Plan for Danube region (2016 - 2021) severe or moderate droughts occur in the Danube plain nearly every year. The pressure on water resources increases during summer when water abstractions are higher, due to agricultural uses and increased demand from the tourist sector.

In order to achieve the aim of the study the hydrological, meteorological and socio-economic data were used. The monthly observed streamflow data were collected from seven hydrometric stations located in the Danube Plain (Figure 1, Table 1) over the multiyear period 1960/61-2012/2013. The period of study has been chosen depending on the availability of recorded data for all stations in the basin. The hydrological sta-

Table 1. List of hydrometric stations used for the study

\begin{tabular}{|l|l|c|c|c|}
\hline River name & Station name & Elevation $(\mathbf{m}$ a.s.l.) & $\begin{array}{c}\text { Drainage area } \\
\mathbf{k m}^{2} \mathbf{~}\end{array}$ & $\begin{array}{c}\text { Investigated } \\
\text { period }\end{array}$ \\
\hline Topolovets & Akacievo & 250 & 305 & $1961-2015$ \\
\hline Lom & Trajkovo & 442 & 1087 & $1961-2015$ \\
\hline Lom & Gorni Lom & 1100 & 88,5 & $1961-2013$ \\
\hline Vojnishka & Tarnyane & 260 & 269 & $1961-2013$ \\
\hline Stakevska & Falkovets & - & 325 & $1961-2015$ \\
\hline Rosica & Sevlievo & 604 & 1090 & $1961-2015$ \\
\hline Yantra & Veliko Tyrnovo & 545 & 1289 & $1961-2015$ \\
\hline
\end{tabular}

Source: Hydrological reference book of the rivers in Bulgaria, 1957 
Table 2. List of meteorological stations used for the study

\begin{tabular}{|l|c|c|c|c|}
\hline $\begin{array}{l}\text { Meteorological } \\
\text { station }\end{array}$ & Latitude & Longitude & Altitude & $\begin{array}{c}\text { Investigated } \\
\text { period }\end{array}$ \\
\hline Vidin & $43^{\circ} 59^{\prime}$ & $22^{\circ} 51^{\prime}$ & 31 & $1961-2015$ \\
\hline Vratsa & $43^{\circ} 12^{\prime}$ & $23^{\circ} 32^{\prime}$ & 309 & $1961-2015$ \\
\hline Lom & $43^{\circ} 49^{\prime}$ & $23^{\circ} 13^{\prime}$ & 32 & $1961-2013$ \\
\hline Oryahovo & $43^{\circ} 43^{\prime}$ & $23^{\circ} 58^{\prime}$ & 29 & $1961-2013$ \\
\hline Pleven & $43^{\circ} 24^{\prime}$ & $24^{\circ} 37^{\prime}$ & 160 & $1961-2015$ \\
\hline Russe & $43^{\circ} 57^{\prime}$ & $25^{\circ} 57^{\prime}$ & 37 & $1961-2015$ \\
\hline Razgrad & $43^{\circ} 33^{\prime}$ & $26^{\circ} 30^{\prime}$ & 346 & $1961-2015$ \\
\hline Silistra & $44^{\circ} 07^{\prime}$ & $27^{\circ} 16^{\prime}$ & 15 & $1961-2013$ \\
\hline Varna & $43^{\circ} 12^{\prime}$ & $27^{\circ} 57^{\prime}$ & 39 & $1961-2015$ \\
\hline
\end{tabular}

Source: Meteorological yearbook, National Institute of Meteorology and Hydrology

tions are located on different independent small and medium-sized rivers in the Severozapaden (NW Bulgaria) and Severen centralen (NC Bulgaria) regions (Figure1, Table 1). In the Severoiztochen (NE Bulgaria) region there is a lack of reliable hydrological data. Meteorological data are monthly air temperature and precipitation from six meteorological stations situated in Northern Bulgaria (Figure1, Table 2). The month- ly precipitation data were used for calculation Standardized Precipitation Indices (SPI) and the Standardized Precipitation Evapotranspiration indices (SPEI) were calculated based of monthly precipitation and air temperature data. Drought vulnerability was evaluated by utilization of socio-economic data as population density, municipal water use, industrial water use, agricultural water use and water services.

\section{Methodology}

In order to investigate the spatial and temporal extents and severity of meteorological drought occurrence in the study area, Standardized Precipitation Index (SPI) (Mckee et al.1993) and Standardized Precipitation Evapotranspiration Index (SPEI) (VicenteSerrano et al., 2010; Begueria et al., 2010) were used. SPI is standardized and can be computed at different time scales, allowing it to monitor the different kinds of drought (Keyantash \& Dracup, 2002). The SPI calculation for any location is based on the long-term precipitation record for a desired period. This long-term record is fitted to a probability distribution, which is then transformed into a normal distribution, so that the mean SPI for the location and desired period is zero (Edwards \& McKee, 1997). The SPEI is computed as the difference between the cumulative precipitation and the potential evapotranspiration and allow to evaluate the effect of air temperature on drought occurrence and intensity.

The method of Streamflow Drought Index (SDI) developed by Nalbantis \&Tsakiris (2009) was used in this work to characterize the hydrological drought events for the studied area. Its calculation is similar to SPI, and is based on monthly observed streamflow volumes at different time scales. For SDI calculations, the hydrological year started in November and ended in October.
All three indices (SPI, SPEI and SDI) indicate the drought severity according to its intensity and duration. According to the SPI, SPEI and SDI criterion, drought conditions are defined with values lower than o. The descriptions of drought states are provided with the criteria in Table 3.

In the proposed methodology, the reference periods start from November of each year, which is considered the beginning of the hydrological year in Bulgaria. In order to evaluate the drought, the SDI, SPI and SPEI are calculated with a 12 - month time step.

Table 3. Classification of drought conditions according to the SDI and SPI

\begin{tabular}{|l|l|l|}
\hline $\begin{array}{l}\text { Probability } \\
(\%)\end{array}$ & $\begin{array}{l}\text { Drought } \\
\text { Description }\end{array}$ & Criterion \\
\hline 1,7 & Extreme wet & SDI/SPI/SPEI $\geq 2.0$ \\
5,1 & Very wet & $2 \geq \mathrm{SDI} / \mathrm{SPI} / \mathrm{SPEI} \geq 1.5$ \\
9,5 & Moderate wet & $1,5 \geq \mathrm{SDI} / \mathrm{SPI} / \mathrm{SPEI} \geq 1.0$ \\
\hline 67,2 & Normal & $-1.0 \geq \mathrm{SDI} / \mathrm{SPI} / \mathrm{SPEI} \leq 1.0$ \\
\hline 9,5 & Moderate drought & $-1.5 \leq \mathrm{SDI} / \mathrm{SPI} / \mathrm{SPEI} \leq-1.0$ \\
\hline 5,0 & Severe drought & $-2.0 \leq \mathrm{SDI} / \mathrm{SPI} / \mathrm{SPEI} \leq-1.5$ \\
\hline 2,0 & Extreme drought & SDI/SPI/SPEI $\leq-2.0$ \\
\hline
\end{tabular}

Source: MCKEE et al. (1993); Nalbantis and Tsakiris (2009)

Based on drought indices the maximum intensity of dry events is determined according to the classifi- 
cation from table 1. Meteorological and hydrological drought are evaluated in term of their duration and magnitude. The drought duration is determined as a period when the drought indices (SPI, SPEI of SDI) for any of the time scale are below o. With the increasing of time scale each new month has less impact on the total precipitation and this determines the indices which indicate a few dry events but with longer duration (McKee et al. 1993). In the present paper the extreme drought duration is pointed out.

The formula given by Mckee et al. (1993) has been applied in order to assess drought magnitude (DM) as follow:

$$
D M=-\left(\sum_{j-1}^{x} S P I_{i j}\right)
$$

where $\mathrm{j}$ is the first month when SPI becomes negative and $x$ is the last consecutive month with the negative value of the index.

The drought magnitude represents the positive sum of the drought indices that are negative over consecutive months. Instead SPI, SPEI or SDI can be used in the formula for drought magnitude. Drought magnitude $(D M)$ and duration $(D)$ were used for calculation of the average drought intensity over the duration (ADI), (Mckee et al., 1995, Bonaccorso et al., 2003, Zhang et al, 2015).

$$
A D M=\frac{D M}{D}
$$

To calculate the probability of occurrence of a potentially damaging phenomenon we used Drought Hazard Index (DHI) according to the methodology proposed by Shahid et al. and later by Rajsekhar et al. Using a weighting system based on the cumulative distribution function, Weight $(W)$ and rating $(R)$ scores are assigned based on the normal cumulative probability function to drought hazard assessment using severity and occurrence probability. Weight scores are determined by considering the SPI/SDI intervals, such that weight $=1$ for normal to mild drought $(M L D)$, weight $=2$ for moderate drought $(M D)$, weight $=3$ for severe drought $(S D)$, and weight $=4$ for extreme drought $(E D)$. Furthermore, each class receives a rate $\mathrm{R}$ from 1 to 4 , based on its probability of occurrence. The final $D H I$ is aggregated as:

$$
\begin{aligned}
& D H I=(M L D r \cdot M L D w)+(M D r \cdot M D w)+ \\
& +(S D \cdot S D w)+(E D r \cdot E D w)
\end{aligned}
$$

where $M L D r, M D r, S D r$, and $E D r$ represent the ratings of Mild, Moderate, Severe, and Extreme categories, respectively, and $M L D w, M D w, S D w$, and $E D w$ represent the weights of drought categories. The DHI values were then rescaled to a $0-1$ range, and evenly classified into four groups as given in Table 4.

Table 4. DHI, DVI Classification for Hazard and Vulnerability Assessment

\begin{tabular}{|l|l|}
\hline DHI, DVI Values & Classification \\
\hline to 0.25 & Low \\
\hline 0.25 to 0.50 & Moderate \\
\hline 0.50 to 0.75 & High \\
\hline 0.75 to 1.00 & Very high \\
\hline
\end{tabular}

Source: Rajsekhar et al. (2015)

Drought Vulnerability Index (DVI). Vulnerability is a relative measure and it describes the degree to which a socio-economic system or physical assets are either susceptible or resilient to the impact of natural hazards (Wilhelmi \& Wilhite, 2002). Selection of vulnerability indicators is directly relevant to the local study context and the particular hazard (United Nation Development Program, 2004). We selected five socio-economic indicators, which include: population density $(P D)$, municipal water use $(M W U)$, industrial water use $(I W U)$, agricultural water use $(A W U)$ and public water services $(P W S)$. We used data from the National Statistical Institute (Bulgaria) for the period $2010-2016$. The indicator values are turned into their scaled values. Then the Drought Vulnerability Index $(D V I)$ is calculated using the following equitation.

$$
D V I=\frac{P D+M W U+I W U+A W U+P W S}{5}
$$

Based on the value of $D V I$, vulnerable regions were classified under four classes (Table 4).

\section{Results and discussion}

\section{Drought occurrence}

In order to analyze the spatial and temporal distribution of dry years, we have extracted for each station and each year in the investigated period the values of drought indices (SPI-12, SPEI-12, and SDI-12) which correspond to the period from November to October (hydrological year). SPI, SDI, SPEI time series for all stations were investigated to exam temporal drought patterns. According to the adopted classification, the calculated standardized precipitation index (SPI-12) 
Table 5. Number of dry years according to the drought indices

\begin{tabular}{|c|c|c|c|c|}
\hline $\begin{array}{l}\text { Meteorological } \\
\text { stations }\end{array}$ & SPI & SPEI & $\begin{array}{l}\text { Hydrometric } \\
\text { stations }\end{array}$ & SDI \\
\hline \multicolumn{5}{|c|}{ Severozapaden (Northwest) } \\
\hline Vidin & 28 & 29 & Akacievo & 32 \\
\hline Lom & 26 & 27 & Tarnyane & 29 \\
\hline \multirow[t]{3}{*}{ Pleven } & 27 & 28 & Falkovets & 25 \\
\hline & & & Gorni Lom & 25 \\
\hline & & & Traikovo & 27 \\
\hline \multicolumn{5}{|c|}{ Severen centralen (Northcentral) } \\
\hline Ruse & 31 & 28 & Sevlievo & 27 \\
\hline Razgrad & 27 & 26 & Veliko Tarnovo & 28 \\
\hline \multicolumn{5}{|c|}{ Severoiztochen (Northeast) } \\
\hline Varna & 29 & 29 & & \\
\hline
\end{tabular}

in the study area was distinguished from 26 years for Lom (Severozapaden region) to 31 years for Ruse (Severen Centralen region) in which drought occurred of varying intensity (Table 5). SPEI-12 shows between 26 and 29 dry years in most northwest and east parts of the study area. SDI-12 indicates a hydrological drought in 25 to 32 years in Severozapaden region. The number of years with hydrological drought in this region decreases with the increase of altitude (hydrometric stations Falkovets and Gorni Lom) and also from the west (station Akatsievo) to the east (station (Traikovo). The Hydrological drought was observed in 27-28 years in the Severen Centralen region (Table 5)

The present study demonstrates that according to the averaged over the entire area drought indices the occurrence levels of extreme hydrological drought are higher than the meteorological drought. The SPEI-12 shows the lowest occurrence level in Severozapaden region $(1.9 \%)$ and the highest in Severen Centralen region $(3,2 \%)$ where SPI-12 shows extreme drought in only $1,5 \%$ of the investigated years (Table 6 ). SDI12 shows no substantial differences in the occurrence of extreme hydrological drought between the regions (Table 6). The occurrence levels of severe droughts have the highest levels in Severozapaden region (in $6,5 \%$ of the investigated years).

In comparison to SPI and SDI, SPEI shows the increase of frequency of severe drought and a decrease in the occurrence of mild drought. The highest frequency of mild drought was established by SPI for the three investigated regions. The results of the investigation indicate the tendency that the percentage occurrence of the meteorological and hydrological drought events in the studied area is substantially high. However, the frequency of extreme hydrological drought is higher than extreme meteorological drought while for the mild drought SDI is slightly lower than the results obtained by SPI-12 and SPEI12.

Figure 2. presents the distribution of drought indices during the period 1961-2015. Due to a lack of hydrological observation and data, the hydrological drought is investigated for the period 1961-2013.

In most of cases, good synchronicity between meteorological and hydrological drought was observed. The most prolonged drought period both for Severozapaden and Severen centralen regions is 1982/83 - 1995/96 with a short interruption in 1985/86 and 1990/91. Other dry periods are1999/2000 - 2003/04, 2006/07 - 2007/08 and 2010/11 - 2012/13. These periods are clearly manifested in the Severozapaden region, while in Severen centralen region dry periods are shorter or interrupted with a normal year. The beginning of the dry periods is characterized by a clearer manifestation of the meteorological drought, while the hydrological drought is better expressed at the end

Table 6. Drought occurrence - average for Northern Bulgaria in \% of investigated years

\begin{tabular}{|l|c|c|c|c|c|c|c|c|}
\hline \multirow{2}{*}{ Drought Category } & \multicolumn{3}{|c|}{$\begin{array}{c}\text { Severozapaden } \\
\text { (NW Bulgaria) }\end{array}$} & \multicolumn{3}{c|}{$\begin{array}{c}\text { Severen centralen } \\
\text { (NC Bulgaria) }\end{array}$} & \multicolumn{2}{c|}{$\begin{array}{c}\text { Severoiztochen } \\
\text { (NE Bulgaria) }\end{array}$} \\
\cline { 2 - 10 } & SPI 12 & SPEI 12 & SDI 12 & SPI 12 & SPEI 12 & SDI 12 & SPI 12 & SPEI 12 \\
\hline Extreme drought & 2,7 & 1,9 & 4,7 & 1,5 & 3,2 & 4,1 & 2,1 & 2,4 \\
\hline Severe drought & 4,3 & 6,5 & 4,5 & 4,1 & 4,5 & 3,2 & 4,1 & 5,1 \\
\hline Moderate drought & 8,3 & 9,9 & 9,4 & 9,6 & 9,6 & 11,1 & 9,4 & 9,6 \\
\hline Mild drought & 34,7 & 29,6 & 29,4 & 38,3 & 35,2 & 26,6 & 37,2 & 32,4 \\
\hline
\end{tabular}



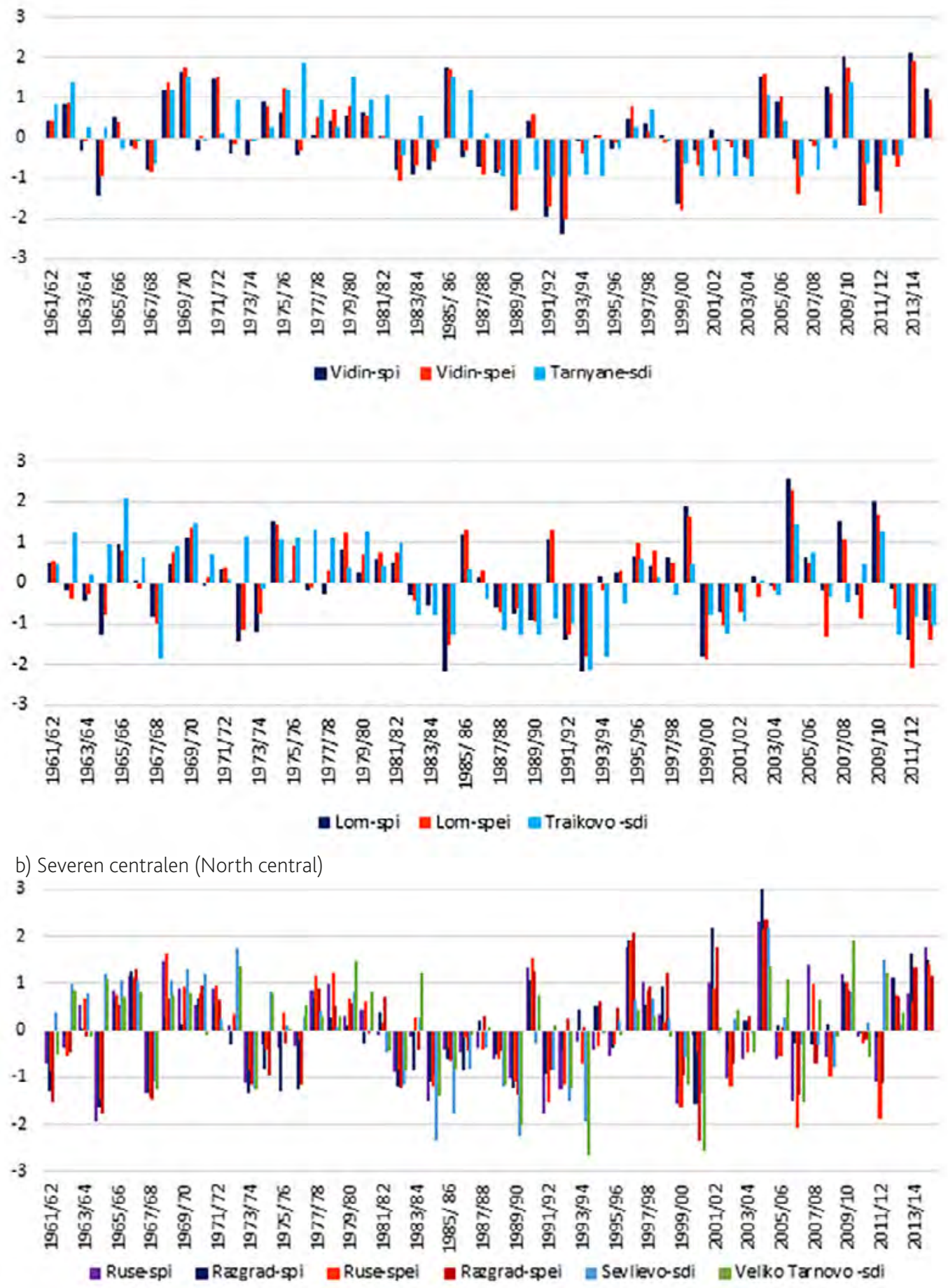

Figure 2. The distribution of SPI-12, SPEI-12 and SDI-12 in selected stations

of the periods and even observed after the end of the metrological drought.

According to SPI and SPEI dry periods in the Severoiztochen region are 1982/83 - 1992/93, 1999/2000 - 2001/02. 2006/07 - 2007/08 and 2011/12. Despite the different investigated period Šurda at al. (2019) found the similar results for the region of Nitra (Slovakia), where the years 2006, 2011 and 2012 were among the driest years.
For the investigated periods, the dry years were observed mainly in $80^{-e s}, 90^{-e s}$ and since 2000. According to European Drought Centre database (see: www. geo.uio.no/edc) the drought in $80^{-e s}$ and $90^{-e s}$ significantly affected the Mediterranean countries, Southeastern Europe, as well as the UK and even Northern Europe. Spinoni et al (2015) also show the occurrence of drought in many European areas during $80^{-e s}$ and $90^{-e s}$.. The temporal distribution of the occurrence 


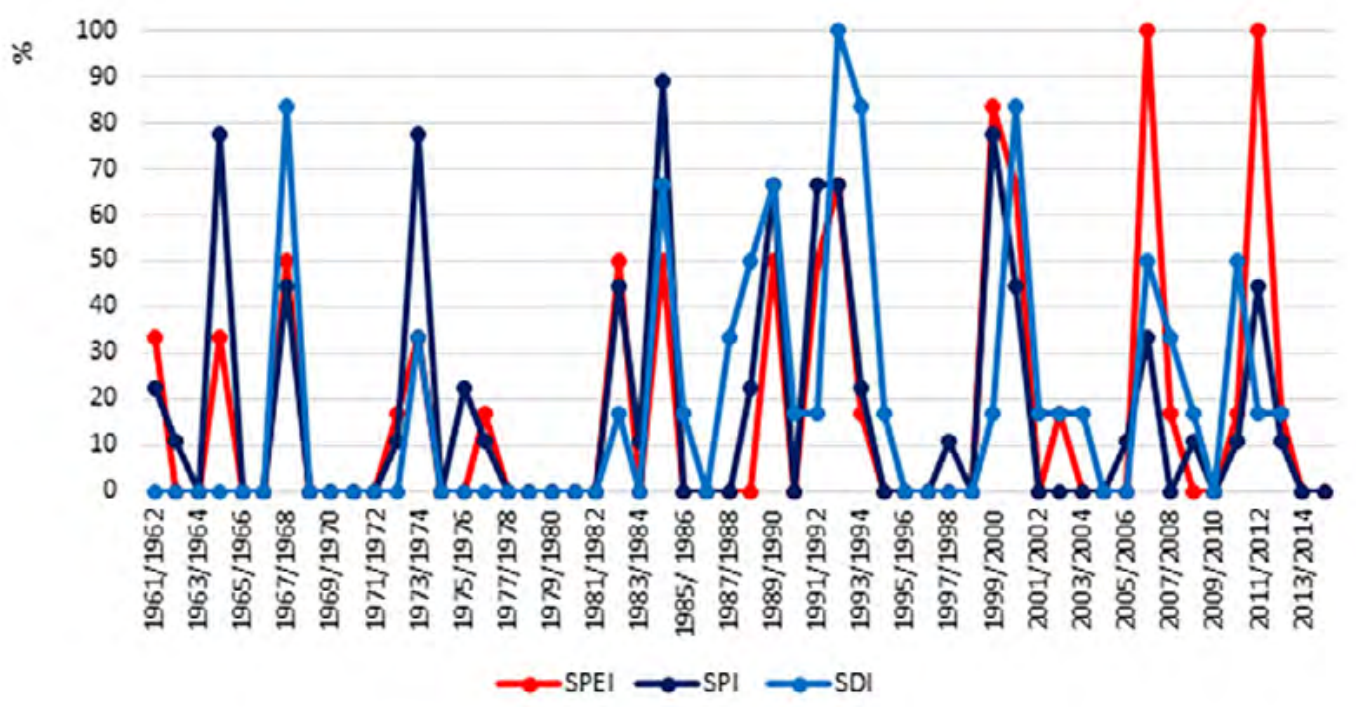

Figure 3. Percentage of investigated stations with dry years (moderately, severely, and extremely)

of different types of droughts in the investigated stations shows synchronicity in the most of cases (Figure3). From the other side, some differences have been observed. During the first decades of the investigated period, dry years are indicated mostly by SPI and SDI while since 2000 the occurrence of dry years determined by SPEI increases. This could be explained with the increase of temperatures during the last decades. The increase of drought in South Europe due to the temperature rise is confirmed also by van der Schrier et al. (2013) and Spinoni et al. (2015a).

According to SPI drought was widespread in $1984 / 1985$ when various types of drought were observed in $90 \%$ of the investigated stations. SPI shows dry years in about $80 \%$ of investigated stations in 1964/1965, 1973/1974 and 1999/2000. SPEI indicates as driest years 2006/2007 and 2011/2012 when the drought occurred in all of the investigated stations. For these years SPI confirms the occurrence of drought in about $35-45 \%$ of the investigated stations and hydrological drought was observed in $50 \%$ of the investigated stations (Figure3). The occurrence of hydrological drought is connected mostly with the precipitation and not with the air temperature.

\section{Drought magnitude and average drought intensity}

Drought magnitude (DM) and average drought intensity (ADI) are investigated based on entire rows of drought indices calculated at step 12 (SPI-12, SPEI-12, and SDI-12) for the investigated period.

The extreme observed values of meteorological drought indices are observed mainly in 2001, 2007 and 2013. For temporal and spatial distribution, the higher synchronicity is observed for SPEI-12, rather than for SPI-12 (Table7). In the Severozapaden region, SPEI indicates extremely low values in January 2001 (2013 for station Pleven). For stations, Vidin and Lom January 2001 was an extremely low SPI-12 as well. On the other side, SPI-12 for station Pleven is showing extremely low in September 1993. For the regions, Severen centralen and Severoiztochen SPEI-12 show extremely low values in 2007 for July and August respec-

Table. 7. Extreme observed values of meteorological drought indices

\begin{tabular}{|c|c|c|c|c|c|c|}
\hline $\begin{array}{l}\text { Meteorological } \\
\text { station }\end{array}$ & SPI-12 & Year & Month & SPEI-12 & Year & Month \\
\hline \multicolumn{7}{|c|}{ Severozapaden (Northwest) } \\
\hline Vidin & -2.81 & 2001 & Jan & -2.47 & 2001 & Jan \\
\hline Lom & -2.88 & 2001 & Jan & -2.53 & 2001 & Jan \\
\hline Pleven & -2.97 & 1993 & Sept & -2.73 & 2013 & Jan \\
\hline \multicolumn{7}{|c|}{ Severen centralen (Northcentral) } \\
\hline Russe & -2.57 & 2001 & Jan & -2.75 & 2007 & Jul \\
\hline Razgrad & -2.09 & 1977 & Apr & -2.95 & 2007 & Jul \\
\hline \multicolumn{7}{|c|}{ Severoiztochen (Northeast } \\
\hline Varna & -3.35 & 1985 & May & -2.58 & 2007 & Aug \\
\hline
\end{tabular}


tively. The occurrence of the extreme values of SPI-12 for the Severen centralen and Severoiztochen regions is asynchronous during the study period.

Extreme values of SDI-12 are observed asynchronously with the extreme meteorological drought indices. In most of cases, the extreme values of SDI-12 are observed in 1994. The lowest extreme hydrological drought event was identified in February 1994 for station Gorni Lom (NW Bulgaria) with a value of - 2.95, and in December 1984 for Yantra river, station Veliko Tarnovo (NC Bulgaria), Table 8.

Table. 8. Extreme observed values of hydrological drought indices

\begin{tabular}{|l|c|c|c|}
\hline Hydrometric stations & SDI-12 & Year & Month \\
\hline \multicolumn{3}{|l|}{ Severozapaden (Northwest) } \\
\hline Tarnyane & -1.20 & 1991 & Jan \\
\hline Falkovets & -2.72 & 2001 & Apr \\
\hline Gorni Lom & -2.95 & 1994 & Feb \\
\hline Traikovo & -2.44 & 1994 & Mar \\
\hline Severen centralen (Northcentral) & & \\
\hline Sevlievo & -2.57 & 1991 & Feb \\
\hline Veliko Tarnovo & -2.68 & 1994 & Dec \\
\hline
\end{tabular}

When the values of the SPI, SPEI and SDI continuously remain negative for consecutive months, the impacts of drought can become more damaging. In order to measure this effect, drought magnitude was calculated. The drought magnitude and drought duration obtained for Northern Bulgaria is shown in Table 9. During the investigated period, the highest drought magnitude (75.17) has been observed in NE Bulgaria (station Varna) where SPI 12 indicates the extreme duration from November 1982 to February 1988 (Table 9). On the other side, the average drought intensity (ADI) is highest for Pleven station, NW Bulgaria (1.64). In comparison to SPI-12, SPEI-12 shows lower DM and ADI. A difference has been established for spatial and temporal distribution as well - DM is highest for NW Bulgaria (station Pleven, 56.44) with the duration from November 2006 to April 2011. The ADI varies from 0.62 (NC Bulgaria) to 1.31 (NE Bulgaria).

DM calculated on the basis of SDI-12 shows higher values, while ADI is close to one established by SPI12. The highest ADI (1.37) according to SDI 12 was observed during the period February 1998 to December 1995 in NW Bulgaria (Table 10).

Table 10. Extreme duration-intensity of hydrological droughts

\begin{tabular}{|c|c|c|c|c|}
\hline $\begin{array}{l}\text { Hydrometric } \\
\text { stations }\end{array}$ & Start & End & DM & ADI \\
\hline & \multicolumn{2}{|c|}{ Duration (months) } & & \\
\hline \multicolumn{5}{|c|}{ Severozapaden (NW Bulgaria) } \\
\hline \multirow{2}{*}{ Tarnyane } & Nov 1988 & Apr 1997 & 86.79 & 0.85 \\
\hline & \multicolumn{2}{|c|}{102} & & \\
\hline \multirow{2}{*}{ Gorni Lom } & Feb 1988 & Dec 1995 & 130.58 & 1.37 \\
\hline & \multicolumn{2}{|c|}{95} & & \\
\hline \multirow{2}{*}{ Traikovo } & Mar 1987 & Feb 1996 & 123.23 & 1.14 \\
\hline & \multicolumn{2}{|c|}{108} & & \\
\hline \multicolumn{5}{|c|}{ Severen centralen (NC Bulgaria) } \\
\hline \multirow{2}{*}{ Sevlievo } & Feb 1985 & Oct 1995 & 156.32 & 1.21 \\
\hline & 129 & & & \\
\hline \multirow{2}{*}{ Veliko Tarnovo } & Sept 1999 & Sept 2002 & 49.42 & 1.34 \\
\hline & 37 & & & \\
\hline
\end{tabular}

Table 9. Extreme duration-intensity of meteorological droughts

\begin{tabular}{|c|c|c|c|c|c|c|c|c|}
\hline \multirow{3}{*}{$\begin{array}{l}\text { Meteorological } \\
\text { stations }\end{array}$} & \multicolumn{4}{|c|}{ SPI-12 } & \multicolumn{4}{|c|}{ SPEI-12 } \\
\hline & Start & End & DM & ADI & Start & End & DM & ADI \\
\hline & \multicolumn{2}{|c|}{ Duration (months) } & & & \multicolumn{2}{|c|}{ Duration } & & \\
\hline \multicolumn{9}{|c|}{ Severozapaden (NW Bulgaria) } \\
\hline \multirow{2}{*}{ Vidin } & Dec 1991 & Jun 1995 & 50.30 & 1.14 & Feb 1992 & Aug 1995 & 48.70 & 1.13 \\
\hline & \multicolumn{2}{|c|}{44} & & & \multicolumn{2}{|c|}{43} & & \\
\hline \multirow{2}{*}{ Pleven } & Jul 1992 & Jul 1995 & 60.57 & 1.64 & Nov 2006 & Apr 2011 & 56.44 & 1.05 \\
\hline & \multicolumn{2}{|c|}{37} & & & \multicolumn{2}{|c|}{54} & & \\
\hline \multicolumn{9}{|c|}{ Severen centralen (NC Bulgaria) } \\
\hline \multirow{2}{*}{ Russe } & Jul 1992 & Feb 1995 & 38.85 & 1.21 & Jan 1988 & Apr 1991 & 24.65 & 0.62 \\
\hline & \multicolumn{2}{|c|}{32} & & & \multicolumn{2}{|c|}{40} & & \\
\hline \multirow{2}{*}{ Razgrad } & Oct 1973 & Feb 1978 & 58.57 & 1.11 & Feb 1974 & Feb 1978 & 43.44 & 0.89 \\
\hline & \multicolumn{2}{|c|}{53} & & & \multicolumn{2}{|c|}{49} & & \\
\hline \multicolumn{9}{|c|}{ Severoiztochen (NE Bulgaria) } \\
\hline \multirow{2}{*}{ Varna } & Nov 1982 & Feb 1988 & 75.17 & 1.17 & Nov 2006 & Nov 2009 & 48.39 & 1.31 \\
\hline & \multicolumn{2}{|c|}{64} & & & \multicolumn{2}{|c|}{37} & & \\
\hline
\end{tabular}




\section{Analysis of the DHI and DVI}

Drought hazard assessment (DHI) for Northern Bulgaria, was calculated by using the probability of occurrence and severity based upon weight and ratings, as described in the methods section. "Low" drought hazard class was detected based on SPI-12, SDI-12, and SPEI -12 in Severozapaden and Severen centralen regions (Table 11). "Moderate" drought hazard based on SPI-12 was detected as 0.25 for station Varna in Northeast Bulgaria (Severoiztochen region). High levels of DHI were not detected in the 12-month time scale for SPIs, SPEIs and SDIs. The DVI was calculated based on five indicators for vulnerability. The scores of the vulnerability index range on a scale from 0,81 (Severoiztochen region) to the most vul- nerable 0,85 (Severen centralen and Severoiztochen regions) (Table 11). According to this analysis, the regions are recognized with the highest vulnerability, with DVI values close to or higher than o.6. Severozapaden and Severen centralen regions are vulnerable in all the five sub-categories, while the Severoiztochen region is less vulnerable to Industrial Water Supply $(0,5)$.

In order to have more detailed information about drought hazard and vulnerability, it is necessary to direct the future study to the local and municipality level. This analysis may help for developing various strategies for mitigation and adaptation to climate change and for effectively tackling environmental and social problems related to water scarcity.

Table 11. DHI and DVI scores for Northern Bulgaria according to the SPI, SDI and SPEI

\begin{tabular}{|l|c|c|c|c|c|c|c|c|}
\hline Regions & \multicolumn{2}{|c|}{ DHI/SPI } & \multicolumn{2}{c|}{ DHI/SDI } & \multicolumn{2}{c|}{ DHI/SPEI } & \multicolumn{2}{c|}{ DVI } \\
\hline & Score & Class & Score & Class & Score & Class & Score & Class \\
\hline Severozapaden & 0.21 & Low & 0.22 & Low & 0.21 & Low & 0.85 & Very high \\
\hline Severen centralen & 0.22 & Low & 0.21 & Low & 0.23 & Low & 0.84 & Very high \\
\hline Severoiztochen & 0.25 & Moderate & - & - & 0.21 & Low & 0.81 & Very high \\
\hline
\end{tabular}

\section{Conclusion}

Accurate drought monitoring and forecasting are essential tools for drought mitigation efforts and reduction of social vulnerability. In this study, the SPI, SPIE, and SDI were proved to be useful indexes for finding out drought severity, magnitude and drought hazard in Northern Bulgaria. Droughts that occurred in the considered stations did not follow a specific order. According to SPI and SDI, the driest multi-year periods were detected in the 1980s and 1990s. In addition, according to SPIE, the driest multi-year periods were after the year 2000. Obtained results showed that the Severozapaden and Severen centralen regions are more prone to extreme drought events, while in the Severoiztochen region the occurrence of severe meteorological drought is higher. The highest drought magnitude according to SPI has been observed in Severoiztochen region, while the average drought intensity (ADI) is highest for Severozapaden region. The drought hazard index identified by using SPI and SDI weight and rating scores between 1960/1961 and 2012/2013 show low values for all stations. The results obtained by this study indicate that North Bulgaria is with a high degree of overall vulnerability to drought. Thus, it is recommended for local authorities to adopt preparatory adaptive measures for drought risk management planning strategies in order to address future drought conditions.

\section{Acknowledgements}

This work has been carried out in the framework of the National Science Program "Environmental Protection and Reduction of Risks of Adverse Events and Natural Disasters", approved by the Resolution of the Council of Ministers № 577/17.08.2018 and supported by the Ministry of Education and Science (MES) of Bulgaria (Agreement № Do1-230/06.12.2018) 


\section{References}

Alexandrov, V. (2006). Soil drought monitoring (review). In the project: Building capacity for sustainable land management in Bulgaria. UNDPGEF, 20052008. C. 42

Alexandrov, V. (ed.) (2011). The drought in Bulgaria. 216 pp. (in Bulgarian)

Alexandrov, V. (ed.) (2011). Methods for monitoring, assessment and impact of drought in Bulgaria. Sofia. pp. 216.

Beguería, S., Vicente-Serrano, S. M., \& Angulo-Martínez, M. (2010). A multiscalar global drought dataset: the SPEIbase: a new gridded product for the analysis of drought variability and impacts. Bulletin of the American Meteorological Society, 91(10), 1351-1356.

Bonaccorso, B., Bordi, I., Cancelliere, A., Rossi, G., \& Sutera, A. (2003). Spatial variability of drought: an analysis of the SPI in Sicily. Water resources management, 17(4), 273-296.

Climate. Proceeding of International Scientific Conference Global Changes and Regional Development (2010). 1617, Sofia.

Dai, A. (2013). Increasing drought under global warming in observations and models. Nature climate change, 3(1), 52-58.

Edwards, D.C, \& McKee, T.B. (1997). Characteristics of 20 th century drought in the United States at multiple scales. Atmospheric Science Paper No. 634, May; $1-30$.

Hagman, G. (1984). Prevention Better than cure: Report on Human and Natural Disasters in the Third World. Stockholm: Swedish Red Cross

Hydrological reference book of the rivers in Bulgaria. (1957). t. I, redaction I. Marinov, M., Science and art.

Georgieva, V., Radeva, S., \& Kazandjiev, V. (2017). On the relationship between atmospheric and soil drought in some agricultural regions of Sough Bulgaria. Bulgarian Journal of Meteorology and Hydrology, 22(3-4), 42-53.

Global Assessment. (2000) Vol. I, edited by Donald A. Wilhite, chap. 1, pp. 3-18 (London: Routledge)

ICID. (2017). Irrigated Agriculture Development under Drought and Water Scarcity. ed. Saeed Nairiz. https://www.icid.org/drought pub2017.pdf

Keyantash, J., \& Dracup, J. A. (2002). The quantification of drought: an evaluation of drought indices. Bulletin of the American Meteorological Socie$t y, 83(8), 1167-1180$.

Koleva, E., \& Alexandrov, V. (2008). Drought in the Bulgarian low regions during the 2oth century. Theoretical and Applied Climatology, 92(1-2), 113120.
McKee, T. B., Doesken, N. J., \& Kleist, J. (1993, January). The relationship of drought frequency and duration to time scales. In Proceedings of the 8th Conference on Applied Climatology (Vol. 17, No. 22, pp. 179-183).

McKee, T. B., Doesken, N.J., \& Kleist, J. (1995). Drought monitoring with multiple time scales. 9th Conf. On Applied Climatology, 1520 January, Dallas, TX, 233236

Miloševic, D., \& Savic, S. (2013). Analysis of precipitation quantities and trends from Pannonian and Peripannonian parts of Serbia. Dela, 39, 125-139.

Nalbantis, I., \& Tsakiris, G. (2009). Assessment of hydrological drought revisited. Water Resources Management, 23(5), 881-897.

National Drought Mitigation Center (NDMC), http:// www.drought.unl.edu, (20 January 2020),

National strategy for management and development of the water sector in Bulgaria (NSMDWS) (2012). Sofia.

Nikolova N., \& Alieva, G. (2011). Drought Periods in Danube River Plain (Bulgaria) in a Changing Climate. Proceeding of International Scientific Conference Global Changes and Regional Development, 1617 , Sofia.

Nikolova, N., Alieva, G., \& Voislavova, I. (2012). Drought periods in non-mountainous part of South Bulgaria on the background of climate change. Geographica Pannonica, 16(1), 18-25.

Petkova, B., Kuzmova, K., \& Berova, M. (2019). The main abiotic stress factors limiting crop cultivation and production in Bulgaria. Climate changes, drought, water deficit and heat stress. Agricultural Sciences/Agrarni Nauki, 11(26).

Popova, Z., Ivanova, M., Martins, D., Pereira, L. S., Doneva, K., Alexandrov, V., \& Kercheva, M. (2014). Vulnerability of Bulgarian agriculture to drought and climate variability with focus on rainfed maize systems. Natural hazards, 74(2), 865-886. DOI 10.1007/s11069-014-1215-3

Popova, Z., Ivanova, M., Pereira, L., Alexandrov, V., Kercheva, M., Doneva, K., \& Martins, D. (2015). Droughts and climate change in Bulgaria: assessing maize crop risk and irrigation requirements in relation to soil and climate region. Bulgarian Journal of Agricultural Science, 21(1), 35-53.

Radeva, K., Nikolova, N., \& Gera, M. (2018). Assessment of hydro-meteorological drought in the Danube Plain, Bulgaria. Hrvatski geografski glasnik, 8o(1), 7-25.

Rajsekhar, D., Singh, V. P., \& Mishra, A. K. (2015). Integrated drought causality, hazard, and vulnerabil- 
ity assessment for future socioeconomic scenarios: An information theory perspective. Journal of Geophysical Research: Atmospheres, 120(13), 6346-6378. http://doi.org/10.1002/2014JD022670

Shahid, S., \& Behrawan, H. (2008). Drought risk assessment in the western part of Bangladesh. Natural hazards, 46(3), 391-413. http://doi.org/10.1007/ $\underline{\text { s11069-007-9191-5 }}$

Spinoni, J., Naumann, G., Vogt, J. V., \& Barbosa, P. (2015). The biggest drought events in Europe from 1950 to 2012. Journal of Hydrology: Regional Studies, 3, 509-524.

Spinoni, J., Naumann, G., Vogt, J., \& Barbosa, P. (2015). European drought climatologies and trends based on a multi-indicator approach. Global and Planetary Change, 127, 50-57.

Szabó, S., Szopos, N. M., Bertalan-Balázs, B., László, E., Milošević, D. D., Conoscenti, C., \& Lázár, I. (2019). Geospatial analysis of drought tendencies in the Carpathians as reflected in a 50-year time series. Hungarian Geographical Bulletin, 68(3), 269-282.

Šurda P., Rončák, P., Vitková, J., \& Tárník, A. (2019). Regional drought assessment based on the meteorological indices for locality Nitra. Acta Hydrologica Slovaca, 20(1), 63 - 73, doi: 10.31577/ahs-20190020.01 .0007 (in Slovak).

Tate, E.L., \& Gustard, A. (2000) Drought Definition: A Hydrological Perspective. In: Vogt J.V., Somma F. (eds) Drought and Drought Mitigation in Europe. (pp. 23-48). Springer, Dordrecht.

Topliiski, D. (2006). Climate of Bulgaria. Sofia: Amstels foundation, pp 360.

Tran, L., Knight, C. G., \& Wesner, V. (2002). Drought in Bulgaria and atmospheric synoptic conditions over Europe. GeoJournal, 57(3), 149-157.

Trnka, M., Olesen, J. E., Kersebaum, K. C., Skjelvåg, A. O., Eitzinger, J., Seguin, B., Peltonen-Sainio, P., Rotter,R., Iglesias, A.,Orlandini, S., \& Dubrovský, M. (2011). Agroclimatic conditions in Europe under climate change. Global Change Biology, 17(7), 22982318.

Trnka, M., Hlavinka, P., \& Semenov, M. A. (2015). Adaptation options for wheat in Europe will be lim- ited by increased adverse weather events under climate change. Journal of the Royal Society Interface, 12(112), 20150721.

Trnka, M., Olesen, J. E., Kersebaum, K. C., Rötter, R. P., Brázdil, R., Eitzinger, J., Jansen, S., Skjelvåg, A.O., Peltonen-Sainio, P., Hlavinka, P. \& Balek, J. (2016). Changing regional weather crop yield relationships across Europe between 1901 and 2012. Climate Research, 70(2-3), 195-214.

United Nation Development Program (2004): Reducing disaster risk. A challenge for development. United Nation Development Program/Bureau for Crisis Prevention and Recovery, New York. Available at: http://www. undp.org/bcpr/disred/rdr.htm.

Urošev, M., Dolinaj, D., \& Leščešen, I. (2016). Hydrological droughts in the Južna Moravia river basin (Serbia). Geographica Pannonica, 20(4), 197-207.

Vicente-Serrano, S. M., Beguería, S., \& López-Moreno, J. I. (2010). A multiscalar drought index sensitive to global warming: the standardized precipitation evapotranspiration index. Journal of climate, 23(7), 1696-1718.

Wilhelmi, O. V., \& Wilhite, D. A. (2002). Assessing vulnerability to agricultural drought: a Nebraska case study. Natural Hazards, 25(1), 37-58.

Wilhite, D. (2000). Drought as a Natural Hazard: Concepts and Definitions. In D.A. Wilhite (ed), Drought: A Global Assessment, London: Routledge, pp. 3-18

Wilhite, D. A., \& Glantz, M. H. (1985). Understanding: the drought phenomenon: the role of definitions. Water international, 10(3), 111-120. https://doi. org/10.1007/s0070400702971

World Meteorological Organization (WMO) (1993). Drought and Desertification. Report on the Eleventh Session of the Commission for Climatology. Havana 1993, WMO/TDNo 605, 68 pp.

Zhang, Z., Chao, B. F., Chen, J., \& Wilson, C. R. (2015). Terrestrial water storage anomalies of Yangtze River Basin droughts observed by GRACE and connections with ENSO. Global and Planetary Change, 126, 35-45. https://doi. org/10.1016/j.gloplacha.2015.01.002. 